\title{
Effectiveness of Passive Joint Mobilisation for Shoulder Dysfunction: A Review of the Literature
}

\author{
Judy Chen \\ Physiotherapy Department, \\ The Prince of Wales Hospital, Sydney, \\ Australia
}

\section{Introduction}

Shoulder pain and stiffness is common in the general community. It is the third most frequent site of musculoskeletal pain after back and neck. Not only does shoulder pain and stiffness impact on the physical functioning, it also contributes significantly to the emotional and psychological distress of the patient. Furthermore, it imposes considerable financial burden on the affected individual and the society. The first half of this chapter will review in detail the literature on the scope of the problems associated with shoulder dysfunction, in particular the prevalence, clinical course, and specific target groups such as the elderly, occupational and sporting groups. It will also review patients with specific medical problems such as spinal cord injury, stroke and diabetes mellitus. In addition personal suffering and the financial burden of shoulder pain, occupational risk factors and prognostic factors will be discussed, and the diagnostic dilemmas associated with shoulder problems will be highlighted.

Many approaches have been employed in the treatment of shoulder disorders. Physiotherapy intervention is often the first line management of this problem, and a wide array of physical therapies has been used, in particular, passive joint mobilisation and exercise therapy. Whilst there is growing evidence for exercise therapy (Ainsworth \& Lewis, 2007; Ginn et al, 1997; Ginn and Cohen, 2005; Grant et al, 2004; Trampas and Kitsios, 2660), there is a paucity of research investigating the effectiveness of this commonly-used technique on shoulder disorder. The second part of this chapter is a descriptive review of the latest evidence in support of the efficacy of passive joint mobilisation in the management of shoulder disorders.

\section{Scope of the problem}

\subsection{Prevalence}

Shoulder pain is a common problem in the general community, with prevalence ranging from 7\% to 34\% (van der Windt et al, 1995; van der Heijden, 1999; Vogt et al, 2003; Luime et 
al, 2004; Picavet \& Schouten, 2003; Pope, 1997). An estimated 20\% of the population will suffer shoulder pain during their lifetime (Pope, et al 1997), with a yearly incidence of 15 new episodes per 1,000 patients seen in the primary care setting (van der Windt et al, 1995). Brox (2003) suggested that half the population has at least one episode of shoulder pain yearly. Furthermore, Pope et al (1997) has found that prevalence of shoulder pain could be influenced by case definition. Hence according to this definition, prevalence could range even higher to $51 \%$. The shoulder is the most frequent site of musculoskeletal pain after the lower back, neck and knee (Parsons et al, 2007; McCormick et al, 1996), and shoulder complaints were found to be the most common contributor to the total incidence figure for non-traumatic arm, neck and shoulder pain (Feleus et al, 2008).

Not everyone consults the general practitioner for their shoulder complaints. It has been estimated that the proportion of the population seeking treatment ranged from between 20\% to 50\% (Picavet and Schouten, 2003; Chard et al, 1991; Badcock et al, 2003; Walker Bone et al 2004). In particular, Chakravarty \& Webley (1990) found only $47 \%$ of elderly patients had consulted their general practitioner about shoulder pain. Chard \& Hazleman (1987, 1991) found underreporting of disorders of shoulder in elderly patients in the hospital and in the community. Fewer than $40 \%$ of subjects sought medical attention for shoulder disorders in the community survey, and from the hospital survey, only 3 out of 21 patients with shoulder symptoms had sought medical treatment. This was probably due to the higher acceptance of illness and disability of the elderly population. Hence the prevalence of shoulder problem is higher than what is quoted in the literature. With the population ageing, the incidence of shoulder dysfunction will continue to rise. This has been reflected in the increasing number of referrals for treatment of shoulder disorders in the current clinical settings.

\subsection{Specific target groups}

Shoulder disorders are commonly encountered in the community, but more prevalent in specific populations such as the elderly, workers involved with repetitive work, those who undertake sports/recreation involving repetitive arm movements, and those with specific medical problems. The following is a brief survey of what has been reported in the literature.

As mentioned previously, surveys have reported a high prevalence of chronic shoulder problems in the elderly in the general community, with rates ranging from $26 \%$ (Chard et al, 1987, 1991) to $34 \%$ (Chakravarty \& Webley, 1990) to $74 \%$ (Vecchio et al, 1995). Shoulder pain, either alone or in conjunction with pain in other joints, has a substantial impact on the function and well-being of older adults (Chakravarty \& Webley, 1990). Of those aged 85 years and over who reported shoulder joint problems, most had difficulty or were dependent on others in activities in daily living (Badley \& Tennant, 1992). Measures of physical performance involving the upper extremity were also decreased in the elderly, together with increased prevalence of joint pain at other body sites (Vogt et al 2003).

Restricted shoulder movement is also common in the elderly, especially in females (Chard \& Hazleman, 1987; Chard et al, 1991). It has been shown that there is a mean of 30 degrees less movement in the elderly as compared with younger subjects, with a 10 degree reduction per 
decade. Prevalence of symptomatic shoulder disorders in the elderly population is high. The potential disability and unmet needs caused by shoulder disorders in the elderly is considerable.

Workers involved in repetitive work and manual handling report higher prevalence rates of shoulder pain than the general community (Silverstein et al, 1998), with considerably higher rates of shoulder pain reported in occupations such as dentists (Fish \& Morris-Allen, 1998; Lalumandier et al, 2001), sewing machine operators (Kaegaard \& Andersen, 2000); forestry workers (Miranda et al, 2001); hotel restaurant workers (Chyuan et al, 2004); computer workers (Brandt et al, 2004); construction workers (Ludewig \& Borstad, 2003), and nursing home and elderly care workers (Luime et al, 2004/2005). The six month prevalence of shoulder pain among workers exposed to repetitive work has been reported to be $45 \%$ (Leclerc et al, 2004). Performing artists also report musculoskeletal problems related to the shoulder. Musicians working in an elevated arm position (eg. violinists, violists, flautists, trumpet players) had a higher prevalence of neck-shoulder pain than those working in a more neutral position (Nyman et al, 2007).

A high incidence of shoulder problems is common in overhead sports (Gohlke et al, 1993), such a baseball (Ruotolo et al, 2006), tennis (Vad et al, 2003), and volleyball (Wang \& Cochrane, 2001). In fact, painful shoulder conditions are the most common musculoskeletal complaint in swimmers, with prevalence rates of as high as $76 \%$ being reported (Pink \& Tibone, 2000; Weldon \& Richardson, 2001). It is also the second most affected joint in golfers (Gosheger et al, 2003), and in world-class badminton players, 52\% of players reported shoulder pain and stiffness (Fahlstrom et al, 2006).

Shoulder pain in individuals with traumatic spinal cord injury is common, and frequently results in chronic debilitating pain recalcitrant to treatment. The incidence of people with spinal cord lesions reporting shoulder pain ranges from 30\% to 69\% (Gironda et al, 2004; Ballinger et al, 2000), with tetraplegics reporting an even higher prevalence of $80 \%$ (McCasland et al, 2006; Samuelsson et al, 2004). In addition, shoulder pain is also not selflimiting in patients with acute traumatic quadriplegia. Waring \& Maynard (1991) reported $23 \%$ of this group of patients still had the same or worse shoulder pain at the 6 months discharge. Regardless of the level of spinal cord injury or the result of functional movement patterns, muscle imbalances around the shoulder joint are thought to contribute to shoulder disorders in wheelchairs users (Sinnott et al, 2000).

Like spinal cord injury, shoulder pain is also a common complication of stroke. Strokerelated shoulder problems have been categorised into frozen shoulder, shoulder-hand syndrome and subluxation (Chard \& Hazleman, 1987). The prevalence of shoulder pain post stroke has been reported ranging from 30\% to 67\% (Sackley et al, 2008; Lindgren et al, 2007). It can impede rehabilitation and has been associated with poorer outcomes and prolonged hospital stay (Turner-Stokes \& Jackson, 2002).

Lundbaek (1957) first described the association between shoulder pain and diabetes mellitus. It was noted that the incidence of adhesive capsulitis was two to four times higher in patients with diabetes than in the general population, and it has been described as the most disabling of the common musculoskeletal manifestations of this disease, affecting up to 
$58 \%$ of people within this population (Thomas et al, 2007; Laslett et al, 2008). In addition, older female patients with diabetes were more likely to report shoulder pain or disability (Laslett et al, 2008).

\subsection{Personal suffering and financial burden}

Studies have reported on the severity and impact of shoulder pain and restriction of movement, and the resultant disability and reduced health of the sufferers. Functional limitations in activities of daily living such as personal care, dressing, washing, cooking, housework, gardening and general activities are commonly reported (Pope et al, 1996; Largacha et al, 2006; Smith et al, 2000). As mentioned before, the impact of personal suffering is more prominent in the elderly (Chard et al, 1991; Chakravarty \& Webley, 1993; Vecchio et al, 1995; Vogt et al, 2003; Smith et al, 2000). Sleep disturbance was the most common complaint in patients with shoulder pain (Andersen et al, 2002; Ostor et al, 2005). Croft et al (1994) and Smith et al (2000) reported up to 83\% of patients with shoulder pain were unable to sleep on the affected side.

The presence of rotator cuff pathology is predictive of impaired physical health quality of life (MacDermid et al, 2004; Chipchase et al, 2000; Smith et al, 2000; Andersen et al, 2002; Ostor et al, 2005; Winters et al, 1999). Self assessment of general health status in patients with common shoulder conditions rank in severity with major medical conditions such as hypertension, congestive heart failure and acute myocardial infarction, and clinical depression (Gartsman et al, 1998; Kaergaard \& Anderson, 2000). Ostor et al (2005) found significant difference in 6 of the 8 domains in SF-36 (self-assessment of general health status questionnaire) between population norms and those with shoulder pain, being especially marked for emotional, physical function and physical role. Badcock et al (2002) also found significant psychological distress and disability scores in subjects reporting unilateral shoulder pain.

Rotator cuff tears can have a profound effect on a person's activity level (Harryman et al, 2003). Lippitt et al, (1993) found patients with a tear could only perform 4.4 of the 12 functions on the Simple Shoulder Test. The greatest functional deficits were the inability to throw overhand and lifting 3.6kg to shoulder level (Lippitt et al, 1993; Largacha et al, 2006; Smith et al, 2000).

Apart from the personal and social costs to sufferers of shoulder dysfunction, direct and indirect health care costs pose significant economic burden on the health care system. Swedish insurance data showed that $18 \%$ of disability payments made for musculoskeletal disorders was spent on neck and shoulder problems (Nygren et al, 1995). Up to 30\% of workers have reported sick leave due to shoulder pain (Kuipers et al, 2006), with sick days ranging from 25 to over 101 days (Ekberg \& Wildhagen, 1996). Silverstein et al (1998) reported the average cost of a claim for an occupational shoulder disorder was nearly $\$$ US16,000, and in 2000, the direct costs for the treatment of shoulder dysfunction in the United States totalled a staggering $\$ 7$ billion (Meislin et al, 2005). Many workers with chronic shoulder pain are unable to resume full-time work (Chipchase et al, 2000) and this has important socio-economic implications as the associated disability is likely to result in time lost from work (Croft et al, 1994). 


\subsection{Prognostic factors}

Little is known about the aetiology of shoulder disorders, hence many studies have aimed to determine the prognostic factors associated with shoulder complaints in order to avoid a protracted clinical course. A multitude of factors such as patient demographics (Kennedy et al, 2006; Zheng et al, 2005), duration of symptoms (Croft et al, 1996; Thomas et al, 2005), pain intensity (van der Windt et al, 1996; Macfarlane et al, 1998), baseline disability (Kuipers et al, 2004; Croft et al, 1996), range of motion (van der Heijden, 1999; Croft et al, 1996), hand dominance (Thomas et al, 2005; Bartolozzi et al, 1994), concomitant neck pain (Thomas et al, 2005; van der Windt et al, 1996), trauma (van der Windt et al, 1996), early presentation (Viikari-Juntura et al, 2000), psychosocial factors (Reilingh et al, 2008; Kuipers et al, 2006), medication (Brox \& Brevik, 1996), injection (van der Windt \& Bouter, 2003), education (Brox \& Brevik, 1996; Reilingh et al, 2008; Feleus et al, 2007), occupation (van der Windt et al, 2000; Cassou et al, 2002; Miranda et al, 2001; Viikari-Juntura et al, 2000; Kaergaard \& Andersen, 2000) and even acromial morphology (Morrison et al, 1997) have been repeatedly identified as potential predictors of outcome; however these are not consistent findings in the literature and results of studies often do not agree.

Increasing age, for example, has been found to be a predictor of outcome in patients with shoulder pain in many studies (Kennedy et al, 2006; Ginn and Cohen, 2004; Linsell ,2006; Miranda, 2001; Morrison, 1997; Ostor, 2005; Pope, 1997; Kuipers et al, 2004); yet just as many studies do not support this (Feleus, 2007; Kennedy et al, 2006; Kuipers et al, 2006; Picavet, 2003; Reilingh et al, 2008; Solomon et al, 2001; Winter et al, 1997; van der Windt, 1996). Similarly gender (female) was found by Cassou et al (2002), Kennedy at al (2006), Picavet (2003), Smith et al (2000) and van der Heijden (1999) to be a predictor of poor outcome, but again other studies did not agree (Feleus, 2007; Kuipers et al, 2006; Pope, 1997; Solomon et al, 2001; van der Windt et al, 1996).

The conflicting and inconsistent outcomes of the prognostic studies could be attributed to the heterogeneity of the studies. There was a wide variety among the studies in terms of the study population, length of follow-up, prognostic factors investigated, outcome measures used and method of analysis. For example, some studies investigated shoulder pain only (Kuipers at al, 2006; Croft et al, 1996; Picavet, 2003; Reilingh et al, 2008; Winters et al, 1999), while others included shoulder pain with or without restriction (Ginn and Cohen, 2004; Kennedy et al, 2006; van der Windt et al, 1996). Treatment of shoulder complaint was included in some study models but not in others. Even when treatment was included, comparison of results was not possible due to the variability of treatment administered, such as physiotherapy with or without surgery (Brox et al, 1993,1999); physiotherapy to strengthen rotator cuff, cortisone injection (Bartolozzi et al, 1994), pendulum exercises and wall-climbing exercises (Chard et al, 1988), exercise aimed at restoring neuromuscular control of the shoulder girdle muscles (Ginn et al, 1997; Ginn and Cohen, 2005), physiotherapy stretching program (Griggs et al, 2000) and general physiotherapy (Kennedy et al, 2006; Linsell et al, 2006).

In general there is no consensus for prognostic indicators that can identify patients at high or low risk of chronicity. Kuipers et al (2004) concluded that there is strong evidence that high pain intensity predicted a poorer outcome and middle age is associated with poor outcome in occupational population. They also found moderate evidence that a long 
duration of symptoms and high baseline disability score predicted a poor outcome. However these results are based on small number of studies with large heterogeneity; therefore the results should be interpreted with caution. It is not known whether subjects in these studies had shoulder pain only, or had both shoulder pain and stiffness. Hence little is known about the prognostic factors associated with painful restricted shoulder dysfunction, and only one study (Zheng et al, 2005) has specifically investigated the clinical course of shoulder symptoms in patients treated conservatively for shoulder pain and stiffness.

\subsection{Occupational risk factors}

Studies of occupational diseases have shown the proportion of workers with neck/shoulder pain is high (Cassou et al, 2002). Occupational factors relating to both physical aspects of the work undertaken as well as psychological factors concerning work and the working environment have been associated with musculoskeletal symptoms in the shoulder. Results from numerous relevant studies evaluating occupational risk factors of shoulder pain are in agreement regarding the occupational physical demands associated with shoulder pain. Biomechanical factors such as heavy workload (Frost et al, 2002), duration of employment (van der Windt, 2000), duration of working above shoulder level (Svendsen et al, 2004; Silverstein et al, 2008; Pope et al, 2001; Harkness, 2003), repetitive movements (Andersen et al, 2002; Frost et al, 2002), awkward postures (Pope et al, 2001) and vibration (van der Windt, 2000) have been attributed as potential causes of shoulder problems in workers.

Psychosocial risk factors have also been reported to be associated with the development of shoulder pain. These include depression (Miranda et al 2005), age (Cassou et al, 2002; Bonde et al, 2003), poor control at work (van der Windt, 2000), job dissatisfaction (van der Windt, 2000), high job demand (Andersen et al, 2002), and poor social support (Kaergaard \& Andersen 2000; Grooten et al 2004). Shoulder pain and poor work conditions have been associated with long term sickness absence amongst workers (Ekberg \& Wildhagen, 1996; Viikari-Juntura et al, 2000). In order to design cost-effective measures for the prevention of shoulder pain, data on the importance of each of these risk factors and the dose-response is needed (Bongers, 2001).

\subsection{Diagnostic dilemma}

The main problem with shoulder studies is that there is no agreement on the diagnosis and classifications of shoulder disorders. This poor agreement between health care providers is due to poor reliability of diagnostic tools and clinical tests. Medical staff and physiotherapists utilise diagnostic classification of shoulder disorders to form the hypothetical framework with which management approach is adopted. Many conditions underlie shoulder pain, yet there is no generally accepted explanation for the aetiology of shoulder problems. Patients with high pain severity, chronic complaints and bilateral involvement represent a diagnostic challenge for clinicians. Furthermore, many patients seen with shoulder disorders have recurrent complaints, and the nature of these complaints varies over the course of time, leading to changes in diagnostic category (Winters et al, 1999). Koester et al (2007) highlighted the difficulty in making a diagnosis in their systematic review of the efficacy of subacromial corticosteroid injection in the treatment of rotator cuff disease. They found that even for a relatively focused topic of rotator cuff disease, there were a variety of pathologic conditions ranging from acute strains to full-thickness cuff tears described in the literature. 


\subsubsection{Interobserver agreement}

Most studies have shown that there is little interobserver agreement among surgeons (Kuhn et al, 2007); physiotherapists (de Winter et al, 1999); rheumatologists (Bamji et al, 1996); and between general practitioners and physiotherapists (Liesdek, 1997) in diagnosing soft-tissue shoulder disorders. In these well-powered studies, all the practitioners were experienced and well-trained. The results showed a disappointingly low observed agreement, in particular, in one study (Liesdek, 1997), where the physiotherapists were not blinded for the diagnosis of the general practitioners, and still, the agreement between the two professions was low. Only one study reported almost perfect inter-observer agreement of the Cyriax method for the assessment of shoulder pain by trained and experienced physiotherapists (Pellecchia et al, 1996).

\subsubsection{Reliability of clinical tests}

A large number of tests are used by clinicians to help with the diagnose shoulder pain, but none of these have been standardized. The sensitivity, specificity, positive predictive value, negative predictive value, interobserver reliability and overall accuracy of commonly-used physical examination tests of the shoulder have been comprehensively evaluated in numerous studies (Calis et al, 2000; Park et al, 2005; Silva et al, 2008; Ostor et al, 2004; Nomden et al, 2009; Dinnes et al, 2003). The results of these studies demonstrated that there is a wide variation in the reliability of these tests, with poor to moderate concordance between observers. This was further confirmed in two recent high quality systematic reviews of clinical tests for shoulder pathology. Hughes et al (2008) reviewed 13 studies which evaluated 14 clinical tests commonly used to diagnose rotator cuff pathology. The authors found that most of the tests for rotator cuff pathology were inaccurate and cannot be recommended for clinical use. Hegedus et al (2008) systematically reviewed studies concerning the accuracy of clinical tests for the shoulder, and they included studies on all shoulder pathology. Of the 45 studies reviewed, half were considered to be of high quality according to the Quality Assessment of Diagnostic Accuracy Studies tool, but only 2 studies had adequate sample size (Park et al, 2005; Litaker et al, 2000). Nonetheless, the review found that no tests demonstrated significant diagnostic accuracy. Hegedus et al (2008) examined 10 of the 13 papers included in the review by Hugh et al (2008), and concurred with their assessment. Both reviews concluded that most physical examination tests used for shoulder pathology are inaccurate.

Based on the findings of the literature it is questionable whether these commonly-used clinical tests are useful at all in differentially diagnosing pathologies of the shoulder. As a result of the low reliability of clinical tests for shoulder problems, imaging techniques have been recommended to be used to better define shoulder lesions (Silva et al, 2008). The following section briefly describes some of the current literature in this area.

\subsubsection{Diagnostic imaging techniques}

Due to the diagnostic dilemma and lack of agreement between observers in their diagnosis of shoulder complaints based on clinical examination, diagnostic imaging techniques such as diagnostic ultrasound and magnetic resonance imaging (MRI) are increasingly being used to evaluate patients with painful shoulders. 


\subsubsection{Ultrasound}

Ultrasound is commonly used to diagnose soft tissue disorders of the shoulder (Ptasznik, 2001). Numerous studies have found ultrasonography to be highly accurate for detecting full-thickness rotator cuff tears, characterising their extent, and visualising dislocations of the biceps tendon (Teefey et al, 2000; Moosikasuwan et al, 2005; Naredo et al, 2002). In addition, ultrasound has been used in detecting acromioclavicular pathologies in 30 patients with anterior shoulder pain (Blankstein et al, 2005). When compared with 30 asymptomatic controls, degenerative changes which were undetected in plain radiographs were found in the patient group.

Milosavljevic et al (2005) evaluated the accuracy of high-resolution ultrasonography compared to arthroscopy in the detection of rotator cuff tears preoperatively in 190 shoulders. Ultrasound correctly depicted 118 of 124 rotator cuff tears, all 94 full-thickness tears, and 24 of 30 partial-thickness tears. They concluded that ultrasound is a highly accurate diagnostic method for detecting full-thickness rotator cuff tears, but is less sensitive in detecting partial-thickness rotator cuff tears. This is in agreement with the results of Norregaard et al (2002) who found ultrasound to be less sensitive for detecting partialthickness rotator cuff tears and ruptures of the biceps tendons. Nonetheless ultrasound is quick, non-invasive, and relatively inexpensive; hence it should be used wherever possible to improve diagnosis and treatment of painful shoulder even though the effectiveness of ultrasound is dependent on the type of disorder and the skills and experience levels of the operator (O'Connor et al, 2005).

\subsubsection{Magnetic Resonance Imaging (MRI)}

Magnetic resonance imaging (MRI) is used to detect joint disorders in the shoulder. It is considered an excellent non-invasive method of diagnosing shoulder problems (Toyoda et al, 2005; Mohtadi et al, 2004; Bearcroft et al, 2000). It has also been used to help in the planning of rotator cuff repairs (Ertl et al, 1998). Management plans have been shown in a literature review by Bearcroft (2000) to be subsequently changed due to the impact of MRI on the clinician's diagnosis. The impact on the clinician's diagnosis varied widely between papers: the primary diagnosis was altered in $23 \%$ to $68 \%$ of cases, and the management plans were subsequently changed in $15 \%$ to $61 \%$ of cases.

The effectiveness of MRI has been compared with ultrasound. In a systematic review of the effectiveness of diagnostic tests for the assessment of shoulder pain due to soft tissue disorders, Dinnes et al (2003) concluded that MRI and ultrasound could equally be used for detection of full-thickness rotator cuff tears, although ultrasound may be better at picking up partial tears, and MRI are accurate for detection of full-thickness rotator tears. When patients' perceptions and satisfaction with MRI and ultrasound were compared, most patients with shoulder pain preferred sonography to MRI (Middleton et al 2004). Given the large differential in the cost of the two procedures and patient satisfaction, the implication from current evidence is that ultrasound is the more cost-effective and preferred test for identification of full-thickness tears.

\subsection{Asymptomatic rotator cuff tears}

Clinical decisions of shoulder management should be based on the correlation of physical examination with investigative procedures as many patients could be clinically 
asymptomatic. In fact, magnetic resonance imaging and ultrasound studies have identified a high incidence of asymptomatic rotator cuff tears in the community, especially in the ageing population (Schibany et al, 2004; Milgrom et al, 1995; Miniaci et al, 1995; Yamaguchi et al, 2001; Yamaguchi et al, 2006). There is a high correlation between the onset of rotator cuff tears (either partial or full thickness) and increasing age. Surprisingly despite positive findings of rotator cuff tears on MRI, some individuals reported no pain or functional deficits, although strength was significantly lower in those with complete supraspinatus tendon tear (Schibany et al, 2004). Apart from the older population, Connor et al (2003) found $40 \%$ dominant shoulders of asymptomatic shoulders of overhead athletes had clinical findings consistent with partial or full thickness rotator cuff as compared with $0 \%$ of the non-dominant shoulders. None of these athletes reported any symptoms 5 years later. Indeed Miniaci et al (1995) also found a wide array of abnormal MRI signals in shoulders of young asymptomatic individuals.

\section{Evidence of the effectiveness of passive joint mobilisation}

Whilst many approaches have been employed in the treatment of shoulder disorders, ranging from surgical to pharmacologic interventions such as oral drug therapy and intraarticular injections, non-pharmacologic interventions such as physiotherapy intervention is often the first line management for shoulder problems, with $53 \%$ to $79 \%$ of general practitioners referring to physiotherapists (Gentle et al, 1994; Glazier et al, 1998, van der Windt et al, 1995). Peters et al (1994) found shoulder pain accounts for up to $10 \%$ of all referrals to physiotherapists in Australia which was similar to findings of Hackett et al (1993).

A wide array of physical therapies is commonly used to treat shoulder disorders, including passive joint mobilisation which is commonly used by physiotherapists in the treatment of musculoskeletal disorders. They are procedures designed to increase the joint range of movement by positioning of the joint and the application of oscillatory movements of that joint in various available ranges. Determination of dosage can be modification of duration, intensity or position of the joint (Maitland 1991). Investigators have examined the physiological effects of passive joint mobilisation (Vicenzino et al, 2007; Teys et al, 2008) and the most effective positions and techniques to perform passive joint mobilisations to optimise the effects (Hsu et al, 2002; Vermuelen et al, 2006; Yang et al, 2007). However, there was a paucity of research specifically investigating the effects of passive joint mobilisation on shoulder disorders as this treatment mode was usually embedded in a package of standardised treatment program. Hence the efficacy of this commonly-used intervention for shoulder disorders has not been established until now.

The following literature review will examine the evidence in support of the efficacy of passive mobilisation directed to shoulder region joints only, in the management of shoulder disorders. To ensure only high quality studies are included, the National Health and Medical Research Council (Australia) evidence hierarchy guidelines and the Physiotherapy Evidence Database (PEDro) rating scale have been used as a guide in this review. Where available, only Level I systematic reviews/meta-analysis And/or Level II evidence of randomised controlled trials of moderate to high quality, rating 5 or more on the PEDro scale are included. 
The National Health and Medical Research Council (NHMRC) in Australia has been engaged in the development of evidence-based clinical practice guidelines to rate the strength of evidence in research trials. The strength of evidence includes the level of evidence, quality of evidence and magnitude of treatment effect. The level of evidence reflects on the study design used by the investigators to minimise bias. The quality of evidence assesses the methodological quality of the study. The highest level of evidence (Level I) is represented by a systematic review of high-quality randomised controlled clinical trials measuring relevant outcomes which demonstrates a strong, clinically important, beneficial effect of the intervention. Level II evidence is provided by at least one properly designed randomised controlled trial.

The Physiotherapy Evidence Database (PEDro) contains abstracts of systematic reviews, randomised controlled trials and evidence-based clinical practice guidelines in physiotherapy. The trials have been rated for quality using a rating scale which has sufficient reliability for use in systematic reviews of physical therapy randomised controlled trials (Sherrington et al, 2000; Maher et al, 2003). Studies are rated against a checklist which identifies the internal validity and statistical interpretability of the trials. To assess internal validity the following aspects are included: random allocation, concealment of allocation, comparability of groups at baseline, blinding of patients, therapists and assessors, analysis by intention to treat and adequacy of follow-up. To assess interpretability, between-group statistical comparisons and reports of point estimates and measure of variability are included. The PEDro score is determined by counting the number of checklist criteria that are satisfied in the trial report. The total maximum score is ten. Of note, PEDro does not rate the external validity of the trial.

For this review, a search of the literature was conducted using the Cumulative Index of Nursing Allied Health Literature; MEDLINE; EMBASE from January 1980 to April 2011. Search limits were set to include English language, abstract and human studies. Key search terms included shoulder, shoulder pain, shoulder stiffness, shoulder impingement, physiotherapy, exercise, manual therapy, mobilisation, manipulation and rehabilitation. Inclusion criteria required randomised controlled trials where some form of shoulder "diagnosis" or dysfunction symptoms and some form of manual/manipulative therapy with or without adjunctive or multimodal therapy were used. Articles were excluded when the pain was referred from a spinal source; if there was surgical intervention; sinister pathology such as infection, malignancy, widespread neurological symptoms etc; and contra-indications for manual/manipulative therapy (eg RA, ligamentous instability). The articles were not included if a specific diagnosis of adhesive capsulitis or frozen shoulder was used, unless the article was identified in a systematic review. In addition, conference proceedings, non-peer reviewed literature and case reports were not included.

All relevant articles were read, synthesised and assessed with the PEDro scale. Only those articles which have scored 5 or more on the PEDro rating scale have been included in this review. Essential requirements were randomisation and blinding, with allocation concealment, intention-to-treat and adequate power desirable. A total of 178 citations were retrieved of which 11 met the inclusion/exclusion criteria. Very few peer-reviewed articles restricted passive joint mobilisation to the shoulder region joints alone. Manual therapy/passive joint mobilisation was often part of a multimodal treatment package included with exercise, electrical modalities, massage, stretching etc. The findings of these studies are summarised in Table 1. 


\begin{tabular}{|c|c|c|c|c|c|}
\hline Author & Population Details & tervention & Control & Outcome M easures & Results \\
\hline Nicholson 1985 & $\begin{array}{l}\text { Pain, restriction GHJ } \\
n=20 \\
\text { Age }=51-55\end{array}$ & $\begin{array}{l}\text { Passive joint mobilisation (PJM)- } \\
\text { glenohumeral joint (GHJ); active } \\
\text { exercises } \\
\text { Frequency: } 2-3 x / w k \\
4 \text { weeks }\end{array}$ & $\begin{array}{l}\text { Active exercises within } \\
\text { restriction; resistive } \\
\text { exercise to increase } \\
\text { strength }\end{array}$ & $\begin{array}{l}\text { Pain } \\
\text { Range of motion (ROM) } \\
\text { Follow-up: } 4 \text { weeks }\end{array}$ & $\begin{array}{l}\text { Passive abduction imp } \\
\text { mobilisation group; } \\
\text { No difference in pain } \\
\text { groups }\end{array}$ \\
\hline $\begin{array}{l}\text { Conroy \& } \\
\text { Hayes } 1998\end{array}$ & $\begin{array}{l}\text { Primary impingement } \\
\text { syndrome; pain, limited } \\
\text { functional movement } \\
\text { pattern } \\
\mathrm{n}=14 \\
\text { Age }=50-55\end{array}$ & $\begin{array}{l}\text { PJM of GHJ, and multiple } \\
\text { physical therapy modalities (hot } \\
\text { packs, active ROM, stretching, } \\
\text { strengthening, soft tissue } \\
\text { mobilisation, patient education) } \\
\text { Frequency: } 3 x / \text { wk } \\
3 \text { weeks }\end{array}$ & $\begin{array}{l}\text { Multiple physical } \\
\text { therapy modalities }\end{array}$ & $\begin{array}{l}\text { Pain } \\
\text { Active ROM } \\
\text { Function } \\
\text { Follow-up: } 24 \text { hours, } 3 \\
\text { weeks }\end{array}$ & $\begin{array}{l}\text { Mobilisation group: } \mathrm{d} \\
\text { pain and pain with su } \\
\text { compression test } \\
\text { Control group: increas } \\
\text { function } \\
\text { No difference betwee } \\
\text { mobility, functional ge }\end{array}$ \\
\hline $\begin{array}{l}\text { Van der Windt } \\
\text { et al } 1998\end{array}$ & $\begin{array}{l}\text { Shoulder pain and } \\
\text { stiffness } \\
n=109 \\
\text { Age }=57-60\end{array}$ & $\begin{array}{l}\text { Corticosteroid injection plus } \\
\text { analgesic } \\
2 \times 30 \text { minutes/wk } \\
7 \text { weeks }\end{array}$ & $\begin{array}{l}\text { PJM; exercises; ice } \\
\text { \&/or heat \&/or } \\
\text { electrotherapy (no } \\
\text { ultrasound); analgesics }\end{array}$ & $\begin{array}{l}\text { Self-perceived } \\
\text { improvement } \\
\text { Pain (VAS) } \\
\text { Functional disability } \\
\text { ROM } \\
\text { Follow-up: 7, 26, } 52 \\
\text { weeks } \\
\end{array}$ & $\begin{array}{l}\text { Corticosteroid group: } \\
\text { decrease in pain, incre } \\
\text { function, and passive } \\
\text { No difference betweer } \\
\text { passive abduction RO }\end{array}$ \\
\hline $\begin{array}{l}\text { Winters } \\
\text { et al } 1999\end{array}$ & $\begin{array}{l}\text { 1) Painful stiff shoulders, } \\
\text { "synovial " in origin } \\
\mathrm{n}=114 \\
\text { Age }=46-53 \\
\text { 2) Painful stiff shoulders, } \\
\text { "shoulder girdle" in } \\
\text { origin } \\
\mathrm{n}=58 \\
\text { Age }=43-46\end{array}$ & $\begin{array}{l}\text { 1) "Synovial" } \\
\text { Corticosteroid injection: 1-3 } \\
\text { 2) "Shoulder girdle" } \\
\text { Massage, exercise, electrotherapy }\end{array}$ & $\begin{array}{l}\text { 1)" Synovial" } \\
\text { Massage, exercises, } \\
\text { electrotherapy }(2 x / w k) \\
\text { Mobilisation and } \\
\text { manipulation of } \\
\text { shoulder region and } \\
\text { vertebral column joints } \\
(1 / \text { wk- } 6 \text { weeks }) \\
\text { 2) Mobilisation and } \\
\text { manipulation of } \\
\text { shoulder region and } \\
\text { vertebral column joints }\end{array}$ & $\begin{array}{l}\text { Pain (numerical rating } \\
\text { scale) } \\
\text { Active and passive } \\
\text { ROM } \\
\text { Follow-up: } 2,6,11 \\
\text { weeks }\end{array}$ & $\begin{array}{l}\text { 1) "Synovial" } \\
\text { Improvement in pain } \\
\text { groups } \\
\text { More rapid improvem } \\
\text { injection group } \\
\text { Lower drop out rate d } \\
\text { treatment failure in inj } \\
\text { 2) "Shoulder girdle" } \\
\text { Improvement in both } \\
\text { intensity } \\
\text { Greater and more rapi } \\
\text { improvement in mani } \\
\text { Lower dropout due to } \\
\text { failure in manipulatio }\end{array}$ \\
\hline
\end{tabular}




\begin{tabular}{|c|c|c|c|c|c|}
\hline $\begin{array}{l}\text { Bang \& Deyle } \\
2000\end{array}$ & $\begin{array}{l}\text { Shoulder impingement } \\
\mathrm{n}=52 \\
\text { Age }=42-45\end{array}$ & $\begin{array}{l}\text { Exercise and PJM to shoulder } \\
\text { region joints and shoulder girdle, } \\
\text { and/or upper vertebral column } \\
\text { joints } \\
2 \times / \text { wk for } 3 \text { weeks }\end{array}$ & $\begin{array}{l}\text { Flexibility and } \\
\text { strengthening exercises }\end{array}$ & $\begin{array}{l}\text { Pain (VAS) } \\
\text { Function (self-report } \\
\text { using Likert scale) } \\
\text { Muscle strength } \\
\text { Follow-up: } 1,2 \text { months }\end{array}$ & $\begin{array}{l}\text { Improvements in both } \\
\text { terms of pain, strength } \\
\text { Greater improvement } \\
\text { mobilisation group }\end{array}$ \\
\hline $\begin{array}{l}\text { Bergman } \\
\text { et al } 2004\end{array}$ & $\begin{array}{l}\text { Shoulder pain and } \\
\text { dysfunction } \\
\mathrm{n}=150 \\
\text { Age }=48\end{array}$ & $\begin{array}{l}\text { Manipulative therapy to vertebral } \\
\text { column joints plus usual medical } \\
\text { care } \\
6 \text { sessions over } 12 \mathrm{wks}\end{array}$ & Usual medical care & $\begin{array}{l}\text { Self-perceived } \\
\text { improvement scale } \\
\text { Pain } \\
\text { Functional disability } \\
\text { General health } \\
\text { Follow-up: } 12,26,52 \\
\text { weeks }\end{array}$ & $\begin{array}{l}\text { Similar improvement } i \\
\text { up to } 6 \text { weeks } \\
\text { At } 12 \text { weeks, significar } \\
\text { between groups in pai } \\
\text { and general health in } \mathrm{f} \\
\text { manipulation } \\
\text { At } 52 \text { weeks similar im } \\
\text { both groups }\end{array}$ \\
\hline $\begin{array}{l}\text { Dickens } \\
\text { et al } 2005\end{array}$ & $\begin{array}{l}\text { Subacromial } \\
\text { impingement syndrome; } \\
\text { failed conservative } \\
\text { treatment, awaiting } \\
\text { surgery } \\
\mathrm{n}=85 \\
\text { Age }=55\end{array}$ & $\begin{array}{l}\text { PJM to shoulder region and } \\
\text { vertebral column joints } \\
\text { Exercise therapy, postural advice, } \\
\text { strapping, electrotherapy } \\
\text { Frequency not reported }\end{array}$ & No intervention & $\begin{array}{l}\text { Constant score } \\
\text { Follow-up: } 6 \text { months }\end{array}$ & $\begin{array}{l}\text { Intervention group: all } \\
\text { means of } 20 \text { in Constar } \\
\text { not require surgery } \\
\text { Control group: mean it } \\
\text { in Constant score of } 0 . \\
\text { surgery }\end{array}$ \\
\hline $\begin{array}{l}\text { Chen } \\
\text { et al } 2009\end{array}$ & $\begin{array}{l}\text { Shoulder pain and } \\
\text { stiffness (less than } 140 \\
\text { degrees of active flexion } \\
\text { and abduction; or } \\
\text { greater than } 10 \mathrm{~cm} \text { hand- } \\
\text { behind-back deficit } \\
\text { compared to unaffected } \\
\text { side) } \\
\mathrm{n}=90 \\
\text { Age }=65\end{array}$ & $\begin{array}{l}\text { PJM to shoulder region joints; } \\
\text { exercise to restore neuromuscular } \\
\text { control and advice (avoid painful } \\
\text { activities; pain free exercises) } \\
\text { Up to } 10 \text { sessions over } 8 \text { weeks }\end{array}$ & $\begin{array}{l}\text { Same exercise and } \\
\text { advice as intervention } \\
\text { group }\end{array}$ & $\begin{array}{l}\text { Shoulder Pain and } \\
\text { Disability Index } \\
\text { (SPADI); global } \\
\text { perceived effect; active } \\
\text { shoulder ROM } \\
\text { Follow-up: } 1,6 \text { months }\end{array}$ & $\begin{array}{l}\text { Similar improvement } i \\
\text { measures in both grou } \\
\text { differences between gr } \\
\text { small and statistically } \\
\text { significant }\end{array}$ \\
\hline
\end{tabular}




\begin{tabular}{|c|c|c|c|c|c|}
\hline $\begin{array}{l}\text { Bergman } \\
\text { et al } 2010\end{array}$ & $\begin{array}{l}\text { Shoulder pain, } \\
\text { restriction of movement; } \\
\text { cervicothoracic spine } \\
\text { and rib dysfunction } \\
n=150 \\
\text { Age }=48\end{array}$ & $\begin{array}{l}\text { Manipulative therapy (MT) to } \\
\text { spine only; none to shoulder } \\
\text { region joints; advice } \\
6 \text { sessions over } 12 \text { weeks }\end{array}$ & Usual care & \begin{tabular}{|l} 
Patient perceived \\
recovery \\
Shoulder pain \\
Functional disability \\
General health \\
Economic evaluation \\
Follow-up: $6,12,26$ \\
weeks
\end{tabular} & $\begin{array}{l}\text { At } 6 \text { weeks: no differe } \\
\text { groups } \\
\text { At } 12 \text { weeks: significa } \\
\text { improvement with M } \\
\text { shoulder and neck pai } \\
\text { At } 26 \text { weeks: MT favo } \\
\text { shoulder pain and mo } \\
\text { mobility }\end{array}$ \\
\hline $\begin{array}{l}\text { Bennell } \\
\text { et al } 2010\end{array}$ & $\begin{array}{l}\text { Chronic rotator cuff } \\
\text { disease } \\
\text { Shoulder pain and } \\
\text { restriction } \\
\mathrm{n}=112 \\
\text { Age }=60\end{array}$ & $\begin{array}{l}\text { Soft tissue massage; PJM of } \\
\text { glenohumeral joint; scapular } \\
\text { retraining exercise; taping; home } \\
\text { exercise program } \\
10 \text { sessions over } 8 \text { weeks }\end{array}$ & $\begin{array}{l}\text { Sham ultrasound; } \\
\text { nontherapeutic gel }\end{array}$ & \begin{tabular}{|l} 
SPADI \\
Self-perceived global \\
improvement \\
SF-36 \\
AQoL \\
Isometric shoulder \\
muscle strength; \\
compliance to protocol \\
Follow-up: 11,22 weeks
\end{tabular} & $\begin{array}{l}\text { At } 11 \text { weeks: no signif } \\
\text { difference between gr } \\
\text { SPADI; intervention g } \\
\text { significantly better in } \\
\text { measures and strengt } \\
\text { At } 22 \text { weeks: MT sign } \\
\text { in SPADI, muscle stre } \\
\text { interference with activ }\end{array}$ \\
\hline $\begin{array}{l}\text { Yiasemides } \\
\text { et al } 2011\end{array}$ & $\begin{array}{l}\text { Shoulder pain with } \\
\text { minimal movement } \\
\text { restriction } \\
\mathrm{n}=98 \\
\text { Age }=60\end{array}$ & $\begin{array}{l}\text { Passive mobilisation to shoulder } \\
\text { region joints; exercise and advice } \\
1 \text { or } 2 \text { sessions/week for first } \\
\text { month; where necessary, } \\
\text { additional treatment over } \\
\text { following } 4 \text { weeks to maximum } \\
\text { of } 12 \text { sessions }\end{array}$ & Exercise and advice & $\begin{array}{l}\text { SPADI; self-rated } \\
\text { change; active ROM } \\
\text { (flexion and abduction) } \\
\text { Follow-up: } 1,3,6 \\
\text { months }\end{array}$ & $\begin{array}{l}\text { No statistically signifi } \\
\text { differences in any out } \\
\text { measurements at each }\end{array}$ \\
\hline
\end{tabular}


As can be seen, prior to 2009, only one study had specifically studied the efficacy of the commonly-used physiotherapeutic technique of passive joint mobilisation in the treatment of painful stiff shoulders. Nicholson (1985) investigated the effects of passive joint mobilisation to the shoulder joints and active exercises in patients with painful restricted shoulders. Twenty patients with shoulder pain and limited passive motion at the glenohumeral joint were randomised into an experimental group receiving mobilisation and active exercises or the control group receiving only active exercises. Outcome measures included pain questionnaire and range of glenohumeral motion at baseline and weekly intervals for four weeks. The results demonstrated a mean reduction in pain for the experimental group of -5.1 out of 10 (SD 4.6) compared with -2.9 out of 10 for the control group (SD 4.4). This represented a non-significance difference of -2.2 (95\% CI -6.4 to 2.0). Only passive abduction increased significantly in the experimental group than in the control group. However, due to the small sample size, the study lacked the statistical power to detect small but clinical-meaningful effects of passive joint mobilisation to shoulder region joints.

In 2009, Chen et al conducted a single-blinded randomised clinical trial to assess whether the addition of passive mobilisation of shoulder region joints to advice and exercise for patients with shoulder pain and stiffness was more effective in reducing pain and disability than advice and exercise alone. The experimental group received passive mobilisation directed to the shoulder region joints only. Both experimental and control groups received exercises with proven efficacy which aimed at improving neuromuscular control of the shoulder muscles in order to restore the dynamic stability and muscle force couple coordination of the shoulder region. They also received advice on how to use pain-free methods to perform activities of daily living. No other electrotherapeutic modalities were used. Primary outcome measures included pain and disability measured with the 13-point Shoulder Pain and Disability Index. Secondary outcome measures were self-perceived global improvement measured on a 6-point Likert scale and active ranges of motion. All subjects received a maximum of 10 sessions of therapy, and outcome measurements were performed at baseline, one month and six month post randomisation. Results showed that one month after randomisation, participants in both groups had improved in all outcome measure. Further improvements were seen at six months. However between group differences in all outcome measures were small and statistically non-significant. Hence this study demonstrated that the addition of passive mobilisation of shoulder region joints is not more effective than advice and exercise alone for shoulder pain and stiffness.

Results of the previous study were further supported by Yiasemides et al (2011) who investigated the efficacy of passive mobilisation of shoulder region joints for people with shoulder pain and minimal movement restriction. Participant were randomly allocated to the experimental group where they received passive mobilisation of shoulder region joints, exercise and advice, or to the control group where they received exercise and advice alone. Outcome measures similar to those of Chen et al (2009) were taken at baseline and repeated at 3 and 6 months.

Similarly the results demonstrated that the addition of passive mobilisation of shoulder region joints to exercise and advice is not more effective than exercise and advice alone in decreasing pain and painful range of motion and improving function and self-rated change in symptoms in their cohort, with no significant differences in any of the outcome measurements between the 2 groups at short-, medium-, or longer-term follow-up. 
Other studies have included passive joint mobilisation as a treatment package together with exercises, modalities, corticosteroid injections, massage, taping etc (Conroy and Hayes, 1998; Winter et al, 1999; van der Windt et al, 1998; Dickens et al, 2005; Bennell et al, 2010). Hence it is not possible to tease out the benefits of passive mobilisation directed to the shoulder region joints alone in these studies. Other studies have directed passive joint mobilisation to the cervicothoracic spine and ribs only (Bergman et al, 2004, 2010) or to a combination of spinal and glenohumeral joints (Bang and Deyle, 2000; Winters et al, 1999; Dickens et al, 2005). In these studies, the cervicothoracic spine and adjacent ribs were deemed to be symptomatic. In contrast, McClatchie et al (2009) investigated mobilising asymptomatic cervical spine $(C 5,6,7)$ for shoulder pain with painful arc. They found significant decrease of shoulder pain but no difference in muscle strength following spinal mobilisation.

Systematic reviews have found some evidence in support of manual techniques (van der Heijden et al, 1997; Green et al, 1998; Desmeules et al, 2003; Michener et al, 2004; Grant et al, 2004; Green et al, 2005; Faber et al, 2006; Trampas and Kitsios ,2006; Kuhn, 2009; Kromer et al, 2009; Dorrestijn et al, 2009), but these studies have included the above-mentioned trials (except Bennell et al, 2011), which directed passive joint mobilisation at both shoulder regions joints and the vertebral column joints. Ho et al (2009) conducted a systematic review of randomised controlled trials to determine specifically the effectiveness of manual therapy (MT) for the management of musculoskeletal disorders of the shoulder. The review included studies where at least one application of manual therapy, defined as manipulation, passive joint or soft tissue mobilisation techniques or massage, was applied to either the shoulder girdle, cervical or thoracic spine. Fourteen RCTs were included in this well-designed and comprehensive review. Interventions included joint mobilisations (Bulgen et al, 1984; Conroy and Hayes, 1998; Maricar and Chok, 1999; Vermuelen et al, 2006), mobilisation of the upper quarter (Winters et al, 1997; Bang and Deyle, 2000; Bergman et al, 2004), manipulation (Winters et al, 1997; Bergman et al, 2004), Cyriax' manipulation and deep transverse frictions (Guler-Ulysal and Kozanoglu, 2004), "mobilisation-with-movement" (MWM) (Teys et al, 2008) and soft tissue massage (Van den Dolder and Roberts, 2003). Manual therapy was used in isolation (Winter et al, 1997; Winters et al, 1999; Van den Dolder and Roberts, 2003; Vermuelen et al, 2006; Teys et al, 2008) or in combination with exercises (Nicholson, 1985; Conroy and Hayes, 1998; Maricar and Chok, 1999; Bang and Deyle, 2000; Guler-Ulysal and Kozanoglu, 2004; Citaker et al, 2005), hot packs (Conroy and Hayes, 1998; Citaker et al, 2005) or medical care (Bergman et al, 2004).

The authors concluded that:

- For patients with adhesive capsulitis, MT was not more effective than other interventions in the short term for decreasing pain, improving range of motion (ROM) and function

- For patients with subacromial impingement syndrome, there was conflicting evidence for the use of MT for decreasing pain and improving function in the short term, and moderate evidence that MT was no more effective for improving ROM in comparison to other interventions in the short term

- Combination of soft tissue and joint mobilisation techniques, and therapeutic exercise may be more effective than an exercise program alone

- Conflicting evidence for MT in the management of nonspecific shoulder pain in the short term compared to other interventions 
- Massage and MWM are useful in patients with musculoskeletal disorders of the shoulder in the short term compared with no treatment

However these conclusions do not specify the site at which the manual therapy was directed.

Even though systematic reviews provide the highest level of evidence for clinical trials, due to the heterogeneity of the studies, these reviews are not without their difficulties. Due to the low number of articles meeting inclusion criteria of the reviews, conclusions are often product of critical assessments of trials only, or based on single studies which might be of low methodological quality. The ability to generalise the findings of such studies to inform clinical practice is questionable. This present review specifically investigated the evidence for passive joint mobilisation to the shoulder region joints only and can now provide conclusive evidence that the addition of passive mobilisation to shoulder region joints alone do not confer additional benefit in the short or medium term to exercise and advice alone in the treatment of painful shoulders, with or without restriction (Chen et al, 2009; Yiasemides et al, 2011). It provides evidence that there is immediate benefit in manual therapy and home exercise program in people with chronic rotator cuff disease. There is also evidence to suggest that passive mobilisation to glenohumeral joints, cervicothoracic joints and adjacent ribs, together with exercise and advice may be of value in improving shoulder disorders and that these benefits may accrue over time, especially in terms of improving shoulder function rather than pain.

\section{Conclusion}

Shoulder pain and stiffness is a common and widespread problem affecting many individuals in the community, with even higher prevalence in particular target groups. Not only does shoulder pain and stiffness impact on the physical functioning, it also contributes significantly to the emotional and psychological distress of the patient. Furthermore it also imposes considerable financial burden on the individual and society. The search for a costeffective, evidence-based management for this complex problem is of utmost importance. Prognostic information can help to distinguish between patients with a favourable outcome and those with a high risk of persistent pain and disability, thus facilitating decisions regarding treatment and referral of patients. Little is known about the cause of shoulder disorders and despite the numerous studies identifying the various factors associated with treatment outcome, there is no agreement in the literature on these putative factors, thus rendering the present clinical prediction guidelines inadequate. The main problem is the lack of consensus on the diagnosis of shoulder disorders amongst health care providers. The myriad of clinical tests commonly used by clinicians to help with diagnosis of shoulder problems are of questionable reliability. As a result imaging techniques have been recommended to better define shoulder lesions, yet these are not without their problems and constraints. In addition the validity and reproducibility of the diagnosis and classification system and commonly-used clinical tests for shoulder complaints is inadequate. This lack of agreement regarding the diagnosis of shoulder disorder raises serious doubts about its usefulness. This also underpins the reason that despite the large number of studies conducted, there is little evidence for the treatment of shoulder problems.

The present review has been able to fill the gap in the current literature on the evidencebased management of shoulder dysfunction. Effective treatment should be administered 
according to signs and symptoms rather than diagnosis. Given the competition for the forever decreasing health dollar, it is important that evidence-based and cost-effective treatments are used for shoulder disorders. Further research is needed for a better understanding of the scope of the problem and effectiveness of the different physiotherapy treatment regimes which will help inform and guide clinical practice in the prevention and management of patients with shoulder dysfunction.

\section{References}

[1] Ainsworth R, Lewis JS. (2007). Exercise therapy for the conservative management of full thickness tears of the rotator cuff: a systematic review. Br J Sports Med, 41:200-210

[2] Andersen J, Kaergaard A, Frost P, Thomsen JF, Bonde J, Fallentin N, Borg V, Mikkelsen S. (2002). Physical, psychosocial, and individual risk factors for neck/shoulder pain with pressure tenderness in the muscles among workers performing monotonous, repetitive work. Spine, 27:660-7

[3] Badcock L, Lewis M, Hay E, McCarney R, Croft PR.(2002). Chronic shoulder pain in the community: a syndrome of disability or distress? Ann Rheum Dis, 61:128-31

[4] Badcock L, Lewis M, Hay E, Croft PR. (2003). Consultation and the outcome of shoulderneck pain: a cohort study in the population. J Rheumatol, 30:2694-9

[5] Badley E, Tennant A. (1992). Changing profile of joint disorders with age: findings from a postal survey of the population of Calderdale, West Yorkshire, United Kingdom. Ann Rheum Dis, 51:366-71

[6] Ballinger D, Rintala D, Hart K. (2000). The Relation of shoulder pain and range-ofmotion problems to functional limitations, disability, and perceived health of men with spinal cord injury: a multifaceted longitudinal study Arch Phys Med Rehabil, 81:1575-81

[7] Bamji A, Erhardt C, Price T, Williams P. (1996). The painful shoulder: Can consultants agree? Br J Rheumatol 35:1172-1174

[8] Bang M, Deyle G. (2000). Comparison of supervised exercise with and without manual physical therapy for patients with shoulder impingement syndrome. J Orthop Sports Phys Ther, 30(3):126-137

[9] Bartolozzi A, Andreychik D, Ahmad S. (1994). Determinants of Outcome in the Treatment of Rotator Cuff Disease. Clinical Orthop, 308:90-97

[10] Bearcroft P, Blanchard T, Dixon A, Constant C. (2000). An assessment of the effectiveness of magnetic resonance imaging of the shoulder: a literature review. Skeletal Radiol, 29:673-679

[11] Bennell K, Wee E, Coburn S, Green S, Harris A, Staples M, Forbes A, Buchbinder R. (2010). Efficacy of standardised manual therapy and home exerxcise programme for chronic rotator cuff disease: randomised placebo controlled trial. BMJ, 340:c2756

[12] Bergman GJ, Winters JC, Groenier KH, Pool JJ, Meyboom de-Jong B, Postema K, Van der Heijden GJ. (2004). Manipulative therapy in addition to usual medical care for patients with shoulder dysfunction and pain. Ann Int Med, 141:432-439

[13] Bingefors K, Isacson D. (2004). Epidemiology, co-morbidity, and impact on healthrelated quality of life of self-reported headache and musculoskeletal pain - a gender perspective. Eur J Pain, 8(5):435-50 
[14] Blankstein A, Ganel A, Givon U, Dudkiewicz I, Perry M, Diamant L, Chechik A. (2005). Ultrasonography as a diagnostic modality in acromioclavvicular joint pathologies. Isr Med Assoc J, 7:28-30

[15] Bonde JP, Mikkelsen S, Andersen JH, Fallentin N, Baelum J, Svendsen SW, Thomsen JF, Frost P, Thomsen G, Overgaard E, Kaergaard A and the PRIM Health Study Group. (2003). Prognosis of shoulder tendonitis in repetitive work: a follow-up study in a cohort of Danish industrial and service workers. Occup Environ Med, 60(9):E8

[16] Bongers PM. (2001). The cost of shoulder pain at work. Br Med J, 322:64-5

[17] Brandt LP, Andersen JH, Lassen CF, Kryger A, Overgaard E, Vilstrup I, Mikkelsen S. (2004). Neck and shoulder symptoms and disorders among Danish computer workers. Scand J Work Environ Health, 30(5):399-409

[18] Brox JI. Regional musculoskeletal conditions: shoulder pain. (2003). Best Pract Res Clin Rheumatol , 17(1):33056

[19] Brox JI, Brevik JI. (1996). Prognostic factors in patients with rotator tendinosis (stage II impingement syndrome) of the shoulder. Scand J Prim Health Care,14:100-5

[20] Bulgen DY, Binder Aim Hazleman BL, Dutton J, Roberts S. (1984). Frozen shoulder: perspective clinical study with an evaluation of three treatment regimens. Ann Rheum Dis, 43:353-60

[21] Calis M, Agkun K, Birtane M, Karacan I, Calis H, Tuzun F. (2000). Diagnostic accuracy of the Hawkins and Neer subacromial impingement syndrome. Ann Rheum Dis, 59:44-47

[22] Cassou B, Derriennic F, Monfort C, Norton J, Touranchet A. (2002). Chronic neck and shoulder pain, age and working onditions: longitudinal results from a large random sample in France. Occup Environ Med, 59:537-544

[23] Chakravarty KK, Webley M. (1990). Disorders of the shoulder: an often unrecognised cause of disability in elderly people. BMJ, 300(6728):848-9

[24] Chakravarty KK, Webley M. (1993). Shoulder joint movement and its relationship to disability in the elderly. J Rheumatol, 20:1359-61

[25] Chard MD, Hazleman BL. (1987). Shoulder disorders in the elderly (a hospital study). Ann Rheum Dis, 46:684-7

[26] Chard MD, Hazleman R, Hazleman BL, King RH, Reiss BB. (1991). Shoulder disorders in the elderly: a community survey. Arthritis Rheum,34:766-9

[27] Chen JF, Ginn KA, Herbert RD. (2009). Passive mobilisation of the shoulder region joints plus advice and exercise does not reduce pain and disability more than advice and exercise alone: a randomised trial. Aust J Physiother, 55:17-23

[28] Chipchase L, O'Connor D, Costi J \& Krishnan J. (2000). Shoulder impingement syndrome: Preoperative health status. J Shoulder Elbow Surg, 9: 12-15

[29] Chyuan JY, Du CL, Yeh WY, Li CY. (2004). Musculoskeletal disorders in hotel restaurant workers. Occup Med (Oxford) 54:55-7

[30] Citaker S. Taskiran H, Akdur H, Arabaci UO, Ekici G. (2005). Comparison of the mobilization and proprioceptive neuromuscular facilitation methods in the treatment of shoulder impingement syndrome. The Pain Clinic, 27:197-202 
[31] Connor PM, Banks DM, Tyson AB, Coumas JS, D"Allessandro DF. (2003). Magnetic resonance imaging of the asymptomatic shoulder of overhead athletes. Am J Sports Med, 31:724-727

[32] Conroy DE \& Hayes KW. (1998). The Effect of Joint Mobilization as a Component of Comprehensive Treatment for primary Shoulder Impingement Syndrome. J Orthop Sports Phys Ther, 1: 3-14

[33] Croft P, Pope D, Zonca M, O’Neill T, Silman A. (1994). Measurement of shoulder related disability: results of a validation study. Ann Rheum Dis, 53:525-8

[34] Croft P, Pope D, Silman A. (1996). The clinical course of shoulder pain: prospective cohort study in primary care. Primary Care Rheumatology Society Shoulder Study Group 96. BMJ, 313(7057):601-2

[35] Desmeules F, Cote CH, Fremont P. (2003). Therapeutic exercise and orthopaedic manual therapy for impingement syndrome: a systematic review. Clin J Sport Med, 13:176-82

[36] De Winter AF, Jans MP, Scholten RJ, Deville W, van Schaardenburg D, Bouter LM. (1999). Diagnostic classification of shoulder disorders: Interobserver agreement and determinants of disagreement. Ann Rheum Dis, 58:272-277

[37] Dickens VA, Williams JL, Bahmra MS. (2005). Role of physiotherapy in the treatment of subacromial impingement syndrome: a prospective study. Physiotherapy, 91: 159164

[38] Dinnes J, Loveman E, McIntyre L, Waugh N. (2003). The effectiveness of diagnostic tests for the assessment of shoulder pain due to soft tissue disorders: a systematic review. Health Technol Assess (Winch Eng), 7:iii, 1-166

[39] Dorrestijn O, Stevens M, Winters J, van der Meer K, Diercks R. (2009). Conservative or surgical treatment for subacromial impingement syndrome? A systematic review. J Shoulder Elbow Surg,18:652-660

[40] Ekberg K, Wildhagen I. (1996). Long-term sickness absence due to musculoskeletal disorders: the necessary intervention of work conditions. Scand J Rehab Med, 28:3947

[41] Ertl JP, Kovacs G, Burger RS. (1998). Magnetic resonance imaging of the shoulder in the primary care setting. Med Sci Sports Exer, 30:S7-S11

[42] Faber E, Kuiper JI, Burdofr A, Miedema HS, Verhaar JA. (2006). Treatment of impingement syndrome: a systematic review of the effects on functional limitations and return to work. J Occup Rehabil, 16:7-25

[43] Fahlstrom M, Yeap JS, Alfredson H, Soderman K. (2006). Shoulder pain - a common problem in world-class badminton players. Scand J Med Sci Sports, 16:168-173

[44] Feleus A, Bierma-Zeinstra SMA, Miedema HS, Bernsen RMD, Verhaar JAN, Koes BW. (2008). Incidence of non-traumatic complaints of arm, neck and shoulder in general practice. Manual Therapy, 13:426-433

[45] Feleus A, Bierma-Zeinstra S, Miedema H, Verhagen A, Nauta A, Burdofr A, Varhaar J, Koes B. (2007). Prognostic indicators for non-recovery of non-traumatic complaints at arm, neck and shoulder in general practice -6 months follow-up. Rheumatology, 46:169-176 
[46] Fish DR, Morris-Allen DM. (1998). Musculoskeletal disorders in dentistsNew York State Dental Journal, 64:44-8

[47] Frost P, Bonde JP, Mikkelsen S, Andersen JH, Fallentin M, Kaergaard A, Thomsen JF. (2002). Risk of shoulder tendinitis in relation to the shoulder loads in monotonous repetitive work. Am J Ind Med, 41:11-8

[48] Gartsman GM, Brinker MR, Khan M, Karahan M. (1998). Self-assessment of general health status in patients with five common shoulder conditions. J Shoulder Elbow Surg, 7:228-237

[49] Gentle P, Herlihy P, Roxburgh I. (1994). Controlled trial of open-access physiotherapy service. Br J Gen Pract, 34:371-6

[50] Ginn KA, Herbert RD, Khouw W, Lee R. (1997). A randomized, controlled clinical trial of a treatment for shoulder pain. Phys Ther, 77:802-9

[51] Ginn KA, Cohen ML. (2004). Conservative Treatment for Shoulder Pain. Prognostic Indicators of Outcome. Arch Phys Med Rehabil, $85: 1231-5$

[52] Ginn KA, Cohen M. (2005). Exercise therapy for shoulder pain aimed at restoring neuromuscular control: a randomized comparative clinical trial. J Rehabil Med, 37:115-22

[53] Glazier RH, Dalby DM, Badley EM, Hawker GA, Bell MJ, Buchbinder R, Linekar SC. (1998). Management of common musculoskeletal problems: a survey of Ontario primary care physicians. CMAJ, 158:1037-1040

[54] Gironda RJ, Clark ME, Neugaard B, Nelson A. (2004). Upper limb pain in a national sample of veterans with paraplegia. J Spinal Cord Med, 27:120-7

[55] Gohlke F, Lippert MJ, Keck O. (1993). Instability and impingement of the shoulder of the high performance athlete in overhead stress. Sportverletzung Sportschaden, 7:11521

[56] Gosheger G, Liem D, Ludwig K, Greshake O, Winkelmann W. (2003). Injuries and overuse syndromes in golf. Am J Sport Med, 31:438-443

[57] Grant HJ, Arthur A, Pichora DR. (2004). Evaluation of interventions for rotator cuff pathology: a systematic review. J Hand Ther, 17:274-99

[58] Green S, Buchbinder R, Glazier R, Forbes A. (1998). Systematic review of randomised controlled trials of interventions for painful shoulder: selection criteria, outcome assessment, and efficacy. BMJ, 316:354-360

[59] Green SE, Buchbinder R, Forbes A, Glazier R. (2005). Interventions for shoulder pain. The Cochrane Database of Systematic Reviews, Vol (1)

[60] Griggs SM, Ahn A, Green A. (2000). Idiopathic adhesive capsulitis: a prospective functional outcome study of nonoperative treatment. J Bone Joint Surg, 82-A:13981407

[61] Grooten WJ, Wiktorin C, Norrman L, Josephson M, Tornqvist EW, Alfredsson L. (2004). For the MUSIC-Norrtalje Study Group. Seeking care for neck/shoulder pain: a prospective study of work-related risk factors in a healthy population. J Occup Environ Med, 46:138-146

[62] Guler-Uysal F, Kozanoglu E. (2004). Comparison of the early response to two methods of rehabilitation in adhesive capsulitis. Swiss Med Weekly, 134:353-8 
[63] Hackett GI, Bundred P, Hutton JL, O’Brien J, Stanley IM. (1993). Management of joint and soft tissue injuries in three general practices: value of onsite physiotherapy. $\mathrm{Br} \mathrm{J}$ Gen Prac, 43:61-64

[64] Harkness EF, Macfarlane G.J, Nahit E.S, Silman AJ, McBeth J. (2003). Mechanical and psychosocial factors predict new onset shoulder pain: a prospective cohort study of newly employed workers. Occup Environ Med, 60:850-857

[65] Harryman DT, Hettrich CM, Smith KL, Campbell B, Sidles JA, Matsen FA. (2003). A prospective multipractice investigation of patients with full-thickness rotator cuff tears. The importance of comorbidities, practice, and other covariables on selfassessed shoulder function and health status. J Bone Joint Surg (Am), 85:690-696

[66] Hegedus EJ, Goode A, Campbell S, Morin A, Tamaddoni M, Moorman CT, Cook C. (2008). Physical examination tests of the shoulder: a systematic review with metaanalysis of individual tests. Br J Sports Med, 42:80-92

[67] Ho CCY, Sole G, Munn J. (2009). The effectiveness of manual therapy in the management of musculoskeletal disorders of the shoulder: a systematic review. Manual Therapy, 14:463-474

[68] Hsu AT, Hedman T, Chang JH, Vo C, Ho L, Ho S, Chang L. (2002). Changes in abduction and rotation range of motion in response to simulated dorsal and ventral translational mobilisation of the glenohumeral joint. Phys Ther, 82:544-556

[69] Hughes PC, Taylor NF, Green RA. (2008). Most clinical tests cannot accurately diagnose rotator cuff pathology: a systematic review. Aust J Physiother, 54:159-70

[70] Kaergaard A, Andersen JH. (2000). Musculoskeletal disorders of the neck and shoulders in female sewing machine operators: prevalence, incidence, and prognosis. Occup Environ Med, 57:528-534

[71] Kennedy CA, Manno M, Hogg-Johnson S, Haines T, Hurley L, McKenzie D, Beaton DE. (2006). Prognosis in soft tissue disorders of the shoulder: predicting both change in disability and level of disability after treatment. Phys Ther, 86:1013-1032

[72] Koester MC, Dunn WR, Kuhn J, Spindler KP. (2007). The efficacy of subacromial corticosteroid injection in the treatment of rotator cuff disease: a systematic review. J Am Acad Orthop Surg, 1:3-11

[73] Kromer TO, Tautenhahn UG, de Bie RA, Bart Staal J, Bastiaenen C. (2009). Effects of physiotherapy in patients with shoulder impingement syndrome: a systematic review of the literature. J Rehabil Med, 41:870-880

[74] Kuhn JE. (2009). Exercise in the treatment of rotator cuff impingement. A systematic review and a synthesised evidence-based rehabilitation protocol. J Shoulder Elbow Surg, 18:138-160

[75] Kuhn JE, Dunn WR, Ma B, Wright RW, Jones G, Spencer EE, et al. (2007). Multicenter Orthopaedic Outcomes Network-Shoulder (MOON Shoulder Group). Interobserver agreement in the classification of rotator cuff tears. Am J Sports Med, 35:437-41

[76] Kuijpers T, van der Windt DA, van der Heijden GJ, Bouter LM. (2004). Systematic review of prognostic cohort studies of shoulder disorders. Pain, 109:420-31

[77] Kuijpers T, van der Windt DAWM, Boeke AJP, Twisk JW, Vergouwe Y, Bouter LM, Van der Heijden GJ. (2006). Clinical prediction rules for the prognosis of shoulder pain in general practice. Pain, 120:276-85 
[78] Lalumandier JA, McPHee SD, Parrott CB, Vendemia M. (2001). Musculoskeletal pain: prevalence, prevalence, prevention, and differences among dental office personnel. Gen Dentistry, 49:160-6

[79] Largacha M, Parsons IM 4th, Campbell B, Titelman RM, Smith KL, Matsen F $3^{\text {rd }}$. (2006). Deficits in shoulder function and general health associated with sixteen common shoulder diagnoses: a study of 2674 patients. J Shoulder Elbow Surg 15:30-9

[80] Laslett L, Burnet L, Redmond SP, McNeil CL. (2008). Predictors of shoulder pain and shoulder disability after one year in diabetic outpatients. Rheumatology, 47 :1583-6

[81] Leclerc A, Chastang J-F, Niedhammer I, Landre M-F, Roquelaure Y. (2004). Incidence of shoulder pain in repetitive work. Occup Environ Med, 61:39-44

[82] Liesdek C, van der Windt DAWM, Koes B, Bouter LM. (1997). Soft-tissue disorders of the shoulder. A study of inter-observer agreement between general practitioners and physiotherapists and an overview of physiotherapeutic treatment. Physiotherapy, 83:12-17

[83] Lindgren I, Jonsson A, Norrving B, Lindgren A. (2007). Shoulder pain after stroke: a prospective population-based study. Stroke, 38:343-348

[84] Linsell 1, Dawson J, Zondervan K, Rose P, Randall T, Fitzpatrick R, Carr A. (2006). Prevalence and incidence of adults consulting for shoulder conditions in UK primary care; patterns of diagnosis and referral. Rheumatology, 45:215-221

[85] Lippitt SB, Harryman DT, Matsen FA III. (1993). A practical tool for evaluating function: The simple shoulder test. In Matsen PA III, Fu FH, Hawkins RJ (editors) The Shoulder: A Balance of Mobility and Stability. Rosemont IL: American Academy of Orthopaedic Surgeons, 501-518

[86] Litaker D, Pioro M, El Bilbeisi H, et al. (2000). Returning to the bedside: using the history and physical examination to identify rotator cuff tears. J Am Geriatr So, 48:1633-7

[87] Ludewig P \& Borstad J. (2003). Effects of a home exercise programme on shoulder pain and functional status in construction workers. Occup Environ Med, 60: 841-849

[88] Luime JJ, Koes BW, Hendriksen IJ, Burdorf A, Verhagen AP, Miedma HS, Verhaar JA. (2004). Prevalence and incidence of shoulder pain in the general population: a systematic review. Scand J Rheumatol, 33:73-81

[89] Luime JJ, Kuiper JI, Koes BW, Verhaar JA, Miedema, HS, Burdorf A. (2004). Workrelated risk factors for the incidence and recurrence of shoulder and neck complaints among nursing-home and elderly-care workers. Scand J Work Environ Health, 30:279-86

[90] Luime J, Koes BW, Miedem HS, Verhaar JA, Burdorf A. (2005). High incidence and recurrence of shoulder and neck pain in nursing home employees was demonstrated during a 2-year follow-up. J Clin Epidemiol, 58:407-13

[91] Lundbaek K. Stiff hands in long term diabetics. (1957). Acta Med Scand, 158:447-51

[92] MacDermid JC, Ramos J, Drosdowech D, Faber K, Patterson S. (2004). The impact of rotator cuff pathology on isometric and isokinetic strength, function, and quality of life. J Shoulder Elbow Surg, 13:593-8 
[93] MacDonald PB, Clark P, Sutherland K. (2000). An analysis of the diagnostic accuracy of the Hawkins and Neer subacromial impingement signs. J Shoulder Elbow Surg, 9:299-301

[94] MacFarlane GJ, Hunt IM, Silman AJ. (1998). Predictors of chronic shoulder pain: a population based prospective study. J Rheumatology, 25:1612-5

[95] Maher CG, Sherrington C, Herbert RD, Moseley AM, Elkins M. (2003). Reliability of the PEDro scale for rating quality of randomised controlled trials. Phy Ther, 83:713-21

[96] Maitland GD.(1991) Peripheral Mobilisation (3rd Ed Oxford: Butterworth-Heinemann Chs $4-5$

[97] Maricar NN, Chok B. (1999). A comparison of the effect of manual therapy with exercise therapy and exercise therapy alone for stiff shoulders. Physiotherapy Singapore, 2:99104

[98] McCasland LD, Budiman-Mak E, Weaver FM, Adams E, Miskevics S. (2006). Shoulder pain in the traumatically injured spinal cord patient: evaluation of risk factors and function. J Clin Rheumatol, 12:179-86

[99] McClatchie L, Laprede J, Martin S, Jaglal SB, Richardson D, Agur A. (2009). Mobilisations of the asymptomatic cervical spine can reduce signs of shoulder dysfunction in adults. Man Ther, 14:369-74

[100] Meislin RJ, Sperling JW, Stitik TP. (2005). Persistent shoulder pain: epidemiology, pathophysiology, and diagnosis. Am J Orthop (Belle Mead NJ), 34(12 suppl):5-9

[101] Michener LA, Walsworth MK, Burnet EN. (2004). Effectiveness of rehabilitation for patients with subacromial impingement syndrome: a systematic review. J Hand Ther, 17:152-64

[102] Middleton WD, Payne WT, Teefy SA, Hildebolt CF, Rubin DA, Yamaguchi K. (2004). Sonography and MRI of the shoulder: comparison of patient satisfaction. Am J Roentgenol, 183:1449-52

[103] Milgrom C, Schaffler M, Gilbert S, van Holsbeeck M. (1995). Rotator-cuff changes in asymptomatic adults. The effect of age, hand dominance and gender. J Bone Joint Surg (Br), 77-B:296-298

[104] Milosavljevic J, Elvin A, Rahme H. (2005). Ultrasonography of the rotator cuff: a comparison with arthroscopy in one-hundred-and-ninety consecutive cases. Acta Radiologica, 46:858-865

[105] Mohtadi NG, Vellet AD, Clark ML, Hollinshead RM, Sasyniuk TM, Fick GH, Burton PJ. (2004). A prospective, double-blind comparison of magnetic resonance imaging and arthroscopy in the evaluation of patients presenting with shoulder pain. $J$ Shoulder Elbow Surg, 13:258-65

[106] Moosikasuwan JB, Miller TT, Burke B. (2005). Rotator cuff tears: clinical radiographic, and US findings. RadioGraphics, 5:1591-1607

[107] Naredo E, Aguado P, De Miguel E, Ulson J, Mayorodomo L, Gijon-Banos J, MartinMola E. (2002). Painful shoulder: comparison of physical examination and ultrasonographic findings. Ann Rheum Diseases, 61:132-136

[108] Nicholson GG. (1985). The effects of passive joint mobilization on pain and hypomobility associated with adhesive capsulitis of the shoulder. J Orthop Sports Phys Ther, 6:238-246 
[109] Nomden JG, Slagers AJ, Bergman GJ, Winters JC, Kropmans TJ, Dijkstra PU. (2009). Interobserver reliability of physical examination of shoulder girdle. Manual Therap, 14:152-9

[110] Norregaard J, Krogsgaard MR, Lorenzen T, Jensen EM. (2002). Diagnosing patients with longstanding shoulder joint pain. Ann Rheum Dis, 61:646-9

[111] Nygren A, Berglund A, Von Koch M. (1995). Neck and shoulder pain: an increasing problem. Strategies for using insurance material to follow trends. Scand J Rehabil Med Suppl, 32:107-112

[112] Nyman T, Wiktorin C, Mulder M, Johansson YL. (2007). Work postures and neckshoulder pain among orchestra musicians. Am J Ind Med, 50:370-376

[113] O'Connor PJ, Rankine J, Gibbon WW, Richardson A, Winter F, Miller JH. (2005). Interobserver variation in sonography of the painful shoulder. J Clin Ultrasound, 33:53-6

[114] Ostor AJK, Richards CA, Prevost AT, Speed CA, Hazleman BL. (2005). Diagnosis and relation to general health of shoulder disorders presenting to primary care. Rheumatology, 44:800-805

[115] Park HB, Yokota A, Gill HS, El Rassi G, McFarland EG. (2005). Diagnostic accuracy of clinical tests for the different degrees of subacromial impingement syndrome. $J$ Bone Joint Surg Am, 87:1446-55

[116] Parsons S, Breen A, Foster NF, Letley L, Pincus T, Vogel S Underwood M. (2007). Prevalence and comparative troublesomeness by age of musculoskeletal pain in different body locations. Family Practice, 24:308-316

[117] Pellecchia GL, Paolino J, Connell J. (1996). Inter-tester reliability of the Cyriax evaluation in assessing patients with shoulder pain. J Orthop Sports Phys Ther, 23:3438

[118] Peters D, Davies P, Pietroni P. (1994). Musculoskeletal clinic in general practiced: study of one year's referrals. Br J Gen Pract, 44:25-29

[119] Picavet HS, Schouten JS. (2003). Musculoskeletal pain in the Netherlands: prevalences, consequences and risk groups, the DMC (3)-study. Pain, 102:167-78

[120] Pink MM, Tibone JE. (2000). The painful shoulder in the swimming athlete. Orthop Clin North Am, 31:247-61

[121] Pope D, Croft P, Pritchard C, Macfarlane G, Silman A. (1996). The frequency of restricted range of movement in individuals with self-reported shoulder pain: results from a population-based survey. $\mathrm{Br}$ J Rheumatol, 35:1137-41

[122] Pope DP, Croft PR, Pritchard CM, Silman AJ. (1997). Prevalence of shoulder pain in the community: the influence of case definition. Ann Rheum Dis, 56:308-12

[123] Pope DP, Silman AJ, Cherry NM, Pritchard C, Macfarlane GJ. (2001). Association of occupational physical demands and psychosocial working environment with disabling shoulder pain. Ann Rheum Dis, 60:852-8

[124] Ptasznik R. (2001). Sonography of the shoulder. Van Holsbeeck MT, Introcaso JH, editors. (2001). Musculoskeletal Ultrasound. 2nd Ed. St Louis: Mosby; p.463-516

[125] Reilingh ML, Kuijpers T, Tanja-Harfterkamp AM, van der Windet DA. (2008). Course and prognosis of shoulder symptoms in general practice. Rheumatology, 47:724-730

[126] Ruotolo C, Price E, Panchal A. (2006). Loss of total arc of motion in college baseball players. J Shoulder Elbow Surg, 15:67-71 
[127] Sackley C, Brittle N, Patel S, Ellins J, Scott M, Wright C, Dewey ME. (2008). The prevalence of joint contractures, pressure sores, painful shoulder, other pain, falls and depression in the year after a severely disabling stroke. Stroke, 39:3329-34

[128] Samuelsson KA, Tropp H, Gerdle B. (2004). Shoulder pain and its consequences in paraplegic spinal cord-injured, wheelchair users. Spinal Cord, 42:41-46

[129] Schibany N, Zehetgruber H, Kainberger F, Wurnig C, Basslamah A, Herneth AM, Lang T, Gruber D, Breitenseher MJ. (2004). Rotator cuff tears in asymptomatic individuals: a clinical and ultrasonographic screening study. Eur J Radiology, 51:263268

[130] Sherrington C, Herbert RD, Maher CG, Moseley AM. (2000). PEDro: A database of randomised trials and systematic reviews in physiotherapy. Manual Therapy, 5:223226

[131] Silva L, Andreu JL, Munoz P, Pastrana M, Millan I, Sanz J, Barbadillo C, FernandezCastro M. (2008). Accuracy of physical examination in subacromial impingement syndrome. Rheumatology, 47:679-683

[132] Silverstein B, Welp E, Nelson N, Kalat J. (1998). Claims incidence of work-related disorders of the upper extremities: Washington State, 1987 through 1995. Am J Public Health, 88:1827-1833

[133] Silverstein BA, Bao SS, Fan ZJ, Howard N, Smith C, Spielholz P, Bonauto D, ViikariJuntura E. (2008). Rotator cuff syndrome: personal, work-related psychosocial and physical load factors. J Occup Environ Med, 50:1062-76

[134] Sinnott KA, Milburn P, McNaughton H. (2000). Factors associated with thoracic spinal cord injury, lesion level and rotator cuff disorders. Spinal Cord, 38:748-753

[135] Smith KL, Harryman II DT, Antoniou J, Campbell B, Sigles JA, Matsen III FA. (2000). A prospective, multipractice study of shoulder function and health status in patients with documented rotator cuff tears. J Shoulder Elbow Surg, 9:395-402

[136] Solomon DH, Bates DW, Schaffer JL, Horsky J, Burdick E, Katz JN. (2001). Referrals for musculoskeletal disorders: patterns, predictors, and outcomes. J Rheumatol, 28:2090-5

[137] Svendsen SW, Bonde JP, Mathiassen SE, Stengaard-Pedersen K, Frich LH. (2004). Work related shoulder disorders: quantitative exposure-response relations with reference to arm posture. Occup Environ Med, 61:844-53

[138] Teefey SA, Hasan AS, Middleton WD, Patel M, Wright RW, Yamaguchi K. (2000). Ultrasonography of the rotator cuff: A comparison of ultrasonographic and arthroscopic findings in one hundred consecutive cases. J Bone Joint Surg (Am), 82:498-504

[139] Teys P, Bisset L, Vicenzino B. (2008). The initial effects of a Mulligan's mobilisation with movement technique on range of movement and pressure pain threshold in pain-limited shoulders. Manual Therapy, 13:37-42

[140] Thomas E, van der Windt, DAWM, Han EM, Smidt N, Dziedzic K, Bouter LM, Croft PR. (2005). Two pragmatic trials of treatment of shoulder disorders in primary care: generalisability, course and prognostic indicators. Ann Rheum Dis, 64:1056-61

[141] Thomas SJ, McDougall C, Brown ID, Jaberoo MC, Stearns A, Ashraf R, Fisher M, Kelly IG. (2007). Prevalence of symptoms and signs of shoulder problems in people with diabetes mellitus. J Shoulder Elbow Surg, 16(6):748-51 
[142] Toyoda H, Ito Y, Tomo H, Nakao Y, Koike T, Takaoka K. (2005). Evaluation of rotator cuff tears with magnetic resonance arthrography. Clin Orth Related Res, 439:109-115

[143] Trampas A, Kitsios A. (2006). Exercise and manual therapy for the treatment of impingement syndrome of the shoulder: a systematic review. Phys Ther Reviews, 11:125-142

[144] Turner-Stokes L, Jackson D. (2002). Shoulder pain after stroke: a review of the evidence base to inform the development of an integrated care pathway. Clin Rehabil, 16:27698

[145] Vad VB, Gebeh A, Dines D, Altchek D, Norris B. (2003). Hip and shoulder internal rotation range of motion deficits in professional tennis players. J Sci Med Sport, 6:7175.

[146] Van den Dolder PA, Roberts DL. (2003). A trial into the effectiveness of soft tissue massage in the treatment of shoulder pain. Aust J Physiother, 49:183-8

[147] Van der Heijden GJ (1999). Shoulder disorders: a state-of-the-art review. Best Pract Res Clin Rheumatol, 13:287-309

[148] van der Heijden GJ, van der Windt, DA, de Winter AF. (1997). Physiotherapy for patients with soft tissue shoulder disorders: a systematic review of randomised clinical trials. Br Med Journal, 31:25-30

[149] van der Windt, Koes BW, de Jong BA, Bouter LM. (1995). Shoulder disorders in general practice: incidence, patient characteristics, and management. Ann Rheum Dis, 54:959-964

[150] van der Windt DA, Koes BW, Boeke AJ, Deville W, De Jong BA, Bouter LM. (1996). Shoulder disorders in general practice: prognostic indicators of outcomes. $\mathrm{Br} J \mathrm{Gen}$ Pract, 46(410):519-23

[151] van der Windt DA, Koes BW, Deville W, Boeke AJP, de Jong BA, Bouter LM. (1998). Effectiveness of corticosteroid injections versus physiotherapy for treatment of painful stiff shoulder in primary care: randomised trial. BMJ, 317:1292-1296

[152] Van der Windt DAWM, Koes BW, Deville W, Boeke AJP, deJong BA, Bouter LM (1998) Corticosteroid injections versus physiotherapy for painful stiff shoulder in primary care: randomised trial. BMJ;317:1292-1296

[153] van der Windt DA, Thomas E, Pope DP, de Winter AF, Macfarlane GJ, Bouter LM, Silman AJ. (2000). Occupational risk factors for shoulder pain: a systematic review. Occup Environ Med, 57:433-42

[154] van der Windt DA, Bouter LM. (2003). Physiotherapy or corticosteroid injection for shoulder pain? Ann Rheum Dis, 62:385-387

[155] Vecchio PC, Kavanagh RT, Hazleman BL, King RH. (1995). Community survey of shoulder disorders in the elderly to asses the natural history and effects of treatment. Ann Rheum Dis, 54:152-154

[156] Vermuelen HM, Rozing PM, Oberman WR, le Cessie S, Vliet V, Thea PM. (2006). Comparison of high-grade and low-grade mobilization techniques in the management of adhesive capsulitis of the shoulder: randomized controlled trial. Phys Ther, 86:355--368

[157] Vicenzino B, Paungmali A, Teys P. (2007). Mulligan's mobilization-with-movement, positional faults and pain relief: current concept from a critical review of literature. Manual tTherapy, 12(2):98-108 
[158] Viikari-Juntura E, Takala E, Riihimaki H, Martikainen R, Jappinen P. (2000). Predictive validity of symptoms and signs in the neck and shoulders. J Clin Epidemiol, 53:800-8

[159] Vogt MT, Simonsick EM, Harris TB, Nevitt MC, Kand JD, Rubin SM, Kritchevsky SB, Newman AB. (2003). Neck and shoulder pain in 70- to 79-year-old men and women: findings from the Health, Aging and Body Composition Study. The Spine Journal, 3:435-441

[160] Walker Bone K, Palmer KT, Reading I, Coggon D, Cooper C. (2004). Prevalence and impact of musculoskeletal disorders of the upper limb in the general population. Arthritis Rheum, 51:642-51

[161] Wang CJ, Ko JY, Chen HS. (2001). Treatment of calcifying tendonitis of the shoulder with shock wave therapy. Clin Orthop, 387):83-9

[162] Wang HK, Cochrane T. (2001). Mobility impairment, muscle imbalance, muscle weakness, scapular asymmetry and shoulder injury in elite volleyball athletes. $J$ Sports Med Phys Fitness, 41:403-410

[163] Waring WP, Maynard FM. (1991). Shoulder pain in acute traumatic quadriplegia. Paraplegia, 29:37-42

[164] Weldon EJ, Richardson AB. (2001). Upper extremity overuse injuries in swimming. A discussion of swimmer's shoulder. Clin Sports Med, 20:423-438

[165] Winters JC, Groenier KH, Sobel JS, Arendzen HH, Meyboom-de-Jongh B. (1997). Classification of shoulder complaints in general practice by means of cluster analysis. Arch Phys Med Rehab, 78:1369-74

[166] Winters JC, Sobel JS, Groenier KH, Arendzen JH, Meyboom-de Jong B. (1997). The course of pain and the restriction of mobility in patients with shoulder complaints in general practice. Rheumatology Inter, 16:219-25

[167] Winters JC, Sobel JS, Groenier KH, Arendzen JH, Mayboom-de Jong B. (1997). Comparison of physiotherapy, manipulation, and corticosteroid injection for treating shoulder complaints in general practice: randomised, single blind study. BMJ, 314(7090):1320-1325

[168] Winters JC, Jorritsma W, Groenier KH, Sobel JS, Meyboom-de Jong B, Arendzen HJ. (1999). Treatment of shoulder complaints in general practice: long term results of a randomised, single blind study comparing physiotherapy, manipulation, and corticosteroid injection. BMJ, 318(7195):1395-1396

[169] Winters JC, Sobel JS, Groenier KH, et al. (1997). Comparison of physiotherapy, manipulation and corticosteroid injection for treating shoulder complaints in general practice. J Fam Pract (Journal Club), 45(2):103-4

[170] Winters JC, Sobel JS, Groenier KH, Arendzen JH, Mayboom-de Jong B. (1999). The long-term course of shoulder complaints: a prospective study in general practice. Rheumatology, 38:160-3

[171] Yamaguchi K, Tetro M, Blam O, Evanoff BA, Teefey SA, Middleton WD. (2001). Natural history of asymptomatic rotator cuff tears: A longitudinal analysis of asymptomatic tears detected sonographically. J Shoulder Elbow Surg, 10(3):199-297

[172] Yamaguchi K, Konstantinos D, Middleton WD, Hildebolt CF, Galatz LM, Teefey SA. (2006). The demographic and morphological features of rotator dcuff disease. A comparison of symptomatic and symptomatic shoulders. J Bone Joint Surg (Am), 88:1699-1704 
[173] Yang JL, Chang CW, Chen SY, Wang SF, Lin JJ. (2007). Mobilisation techniques in subjects with frozen shoulder syndrome: randomised multiple-treatment trial. Phys Ther, 87:1307-15

[174] Yiasemides R, Halaki M, Cathers I, Ginn K. (2011). Does passive mobilization of shoulder region joints provide additional benefit over advice and exercise alone for people who have shoulder pain and minimal movement restriction? A randomized controlled trial Phy Ther, 91(2):1-11

[175] Zheng, XH, Simpson JA, van der Windt, DAWM, Elliot AM. (2005). Data from a study of effectiveness suggested potential prognostic factors related to the patterns of shoulder pain. J Clin Epidemiol, 58(8):823-30 


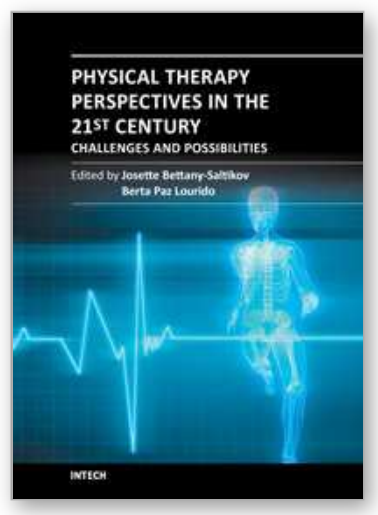

\section{Physical Therapy Perspectives in the 21st Century - Challenges and Possibilities}

Edited by Dr. Josette Bettany-Saltikov

ISBN 978-953-51-0459-9

Hard cover, 386 pages

Publisher InTech

Published online 05, April, 2012

Published in print edition April, 2012

This book contains new information on physical therapy research and clinical approaches that are being undertaken into numerous medical conditions; biomechanical and musculoskeletal conditions as well as the effects of psychological factors, body awareness and relaxation techniques; specific and specialist exercises for the treatment of scoliosis and spinal deformities in infants and adolescents; new thermal agents are being introduced and different types of physical therapy interventions are being introduced for the elderly both in the home and clinical setting. Additionally research into physical therapy interventions for patients with respiratory, cardiovascular disorders and stroke is being undertaken and new concepts of wheelchair design are being implemented.

\section{How to reference}

In order to correctly reference this scholarly work, feel free to copy and paste the following:

Judy Chen (2012). Effectiveness of Passive Joint Mobilisation for Shoulder Dysfunction: A Review of the Literature, Physical Therapy Perspectives in the 21st Century - Challenges and Possibilities, Dr. Josette Bettany-Saltikov (Ed.), ISBN: 978-953-51-0459-9, InTech, Available from:

http://www.intechopen.com/books/physical-therapy-perspectives-in-the-21st-century-challenges-andpossibilities/effectiveness-of-passive-joint-mobilisation-for-shoulder-dysfunction-a-review-of-the-literature

\section{INTECH}

open science | open minds

\author{
InTech Europe \\ University Campus STeP Ri \\ Slavka Krautzeka 83/A \\ 51000 Rijeka, Croatia \\ Phone: +385 (51) 770447 \\ Fax: +385 (51) 686166 \\ www.intechopen.com
}

\author{
InTech China \\ Unit 405, Office Block, Hotel Equatorial Shanghai \\ No.65, Yan An Road (West), Shanghai, 200040, China \\ 中国上海市延安西路65号上海国际贵都大饭店办公楼 405 单元 \\ Phone: +86-21-62489820 \\ Fax: +86-21-62489821
}


(C) 2012 The Author(s). Licensee IntechOpen. This is an open access article distributed under the terms of the Creative Commons Attribution 3.0 License, which permits unrestricted use, distribution, and reproduction in any medium, provided the original work is properly cited. 